\title{
An Exploratory Study of the Level of Sophistication of Management Accounting Practices in Jordan
}

\author{
Nimer Sleihat ${ }^{1}$, Munther Al-Nimer ${ }^{2}$ \& Soud Almahamid ${ }^{1}$ \\ ${ }^{1}$ Faculty of Business, Amman Arab University, Jordan \\ ${ }^{2}$ Faculty of Economics and Administrative Sciences, Applied Science University, Jordan \\ Correspondence: Soud Almahamid, Faculty of Business, Amman Arab University, Jordan. E-mail: \\ soud.almahamid@ahu.edu.jo
}

Received: May 20, 2012

Accepted: June 19, 2012

Online Published: August 8, 2012

doi:10.5539/ibr.v5n9p217

URL: http://dx.doi.org/10.5539/ibr.v5n9p217

\begin{abstract}
Purpose - The research aims to provide a view of the present role of management accounting to identify the extent of usage of management accounting practices (MAPs) and finally to determine the sophistication level of MAPs by employing International Federation of Accountants model (IFAC) in the Jordanian financial sector. Design/methodology/approach - To attain these objectives, the research used the questionnaire method 64 valid questionnaires were returned, giving a $67.3 \%$ response rate. Descriptive statistical analysis was used to analyse the responses. Findings - Regarding the life-cycle stages, it was revealed that $67.2 \%$ of the respondent companies are located in the first two stages. The research reported that traditional practices are still widespread and highly used, rarely using the more sophisticated or advanced practices, and that there is a diversity of practices used in the financial sector context. In general, the research revealed that budgeting practices and financial measures are heavily used, and there is a lack of usage of decision making practices and strategic analysis practices. Concerning the sophistication level of MAPs, the research revealed that almost all of the Jordanian financial sector companies are located in the first stage by $64.1 \%$ and $29.7 \%$ of companies in the second stage based on the IFAC model, thus indicating the simplicity of information that they require. This, in turn, reflects the simplicity of practices that are used in the Jordanian financial sector. Originality/value Provides a broad overview of management accounting practices in the Jordanian financial sector, indicates is a lack of using MAPs in the developing countries, and indicates the improvement which would take place in the Jordanian financial sector in terms of the adoption of more sophisticated or advance MAPs.
\end{abstract}

Keywords: management accounting practices, IFAC model, financial sector, Jordan

\section{Introduction}

The effect of a market economy, intensified competition, globalization, scarce resources, change and complexity in the business environment, and accelerating technological changes drive companies to realize the need to have objective information and awareness of the need for more detailed cost information (Waweru et al., 2005) and these factors in addition required a management accounting system to provide timely and accurate information to facilitate efforts to control costs, measure and improve productivity and pricing decisions (Johnson \& Kaplan, 1987).

Therefore, there is a consensus that the milestone of management accounting practices (MAPs) started with the criticism by Kaplan (1984) and with Johnson and Kaplan (1987) and in turn, this criticism has greatly influenced the evolution of management accounting and global MAPs, consequently contemporary MAPs were generated, for example; Just In Time (JIT), Activity Based Costing (ABC), Activity based budgeting (ABB),Target costs and customer profitability analysis, which provide an important competitive advantage for the organization helping it to create better decision making value, and providing an integrating perspective to the management strategy with useful and relevant information. Accordingly a lot of studies in developed countries explore and emphasise the attention to contemporary MAPs, (Ewert, Wagenhofer, 2006; Adelegan, 2000; Carmona, 2006; Abdel-Kader \& Luther, 2006; Islam \& Kantor, 2005) and examine the benefit which is gained from adopting contemporary practices (Hyvonen, 2005; Chenhall \& Langfield-Smith,1998). 
There are a limited number of studies focusing on MAPs in developing countries (Adelegan, 2000; Sulaiman et al., 2004; Ismail, 2007; Triest, Elshahat, 2007; Kattan, et al., 2007; Billings, Capie, 2004). In addition, many studies indicated that there is a lack of studies which examine the MAPs within the financial sector as most of the studies investigate the MAPs within the industrial or manufacturing sector. Furthermore many researchers indicated the need for examining management accounting within the financial and services sector (Adelegan, 2000; Sulaiman, Ahmad et al., 2004; Wu \& Drury, 2007; Davila \& Wouters, 2006; Billings, Capie, 2004; Garg, et al., 2003; Gutierrez, et al., 2005). Consequently, the current research attempts to remedy this shortage and fill the gap in the management accounting literature and in Jordan as a developing country in particular. It also aims to provide a view of the present role of management accounting to identify the extent of usage of MAPs and to determine the sophistication level of MAPs by employing International Federation of Accountants model (IFAC) in the Jordanian financial sector.

This paper is structured as follows: The next section indicates the significance of the research, followed by reviewing the literature which carried out in MAPs, research design, research methodology, research results, and finally the research conclusions.

\section{Research Significance}

In Jordan, there is a single research paper which investigated MAPs in the industrial sector, (Hutaibat, 2005) which provides an evidence in relation to the shortage in knowledge and empirical studies. Therefore, there is a need for more research in management accounting to fill the gap in this field in developing countries and particularly in Jordan. This research will support and enhance the Jordanian economy to have a full view concerning the status of management accounting and will be useful for both the literature and practitioners.

The application of the IFAC model (IFAC, 1998) which is a model of the development of management accounting, will be used to determine the location of the level of sophistication of current Jordan practices. Moreover, this model has been tested by two studies in management accounting to determine the level of sophistication of MAPs (Adelegan, 2000; Abdel-Kader \& Luther, 2006). The majority of the studies in terms of MAPs have been carried out in manufacturing sectors, (Adelegan, 2000; Sulaiman, et al., 2004; Wu \& Drury, 2007; Davila, Wouters, 2006). However, the financial sector and services firms in general didn't have great attention from researchers and studies in terms of MAPs which was observed through reviewing the literature regarding management accounting studies.

The financial sector has a significant influence on the Jordanian economy; therefore, such a study will be beneficial to this sector which in turn will be beneficial to the Jordan economy as whole.The Jordanian financial sector comprises four main sub-sectors, namely; banking, insurance, diversified financial services, and real estate, (Ministry of Industry and Trade, Jordan, 2007), which it is sensible to investigate the difference between this sector configuration in terms of management accounting. Finally, the findings may shed light on the state of management accounting in other developing countries and will provide a contribution to management accounting practice research in general.

\section{Material Studied}

The concern to study management accounting started in developed countries, as the majority of developed countries have undertaken MAPs to aid their understanding of management accounting and demonstrating research in MAPs within those countries. Such as, (Hopper, 1999; Szychta, 2002; Lamminmaki \& Drury, 2001; Hyvonen, 2005; Abdel-Kader \& Luther, 2006; Wu \& Drury, 2007). Initially, the studies were focused on identifying the role of management accounting information in organizations, (Paige, 1990; Fry, et al., 1995; Jazayeri, Cuthbert, 2004). In the USA, a study revealed that the role of management accounting information in the United States is to provide the critical management information that determined gaols and actions in American companies, (McNair, Vangermeersch, 1996). According to Davila, Foster (2005) a management accounting system plays two main roles; reducing agency costs and facilitating decision making. Reducing agency costs refers to the separation of ownership and control. Lexa, et al. (2005) indicated that managerial accounting utilises a variety of tools to make business decisions more rational and more scientific and added that managers use service activity costing to develop better models of their cost structures. This, in turn, will allow more nuanced contract negotiation and evaluation of proposed changes. In terms of the contemporary role of management accounting system a german study based on 30 interviews with top and middle managers revealed that management accounting systems provide an information context that is required for strategic sense-making (Heidmann, et al., 2008). In Spain, a study revealed that management accounting information plays a significant role in terms of the continuous improvement process and the important role of certain control system elements for evaluating the implementation of the organizations strategy (Lobo, et al., 2008). 
Since the changes which have occurred in the business environment, a lot of studies have attempted to examine the significant changes in management accounting (Hopper, 1999). Several studies were conducted in order to investigate the change in management accounting systems (Ezzamel, 1994; Ezzamel, et al., 1997; Mathejka, Waegenaere, 1999; Naranjo-Gil, Hartmann, 2007; Perera, 2004; Smith, et al., 2005; Strauss, 1992; Vieira, Hoskin, 2005). A survey carried out by Garg, et al. (2004) argued that the management accountant's role has changed and they are increasingly perceived as business partners who focus on key strategic issues well beyond the boundaries of traditional finance. Another argument made by Sulaiman and Mitchell (2005) concluded that contemporary management accounting systems are not static in nature and if change was to significantly enhance management accounting value it should be characterized by a relatively high frequency and positive importance and success rating. Gupta and Gunasekaran (2005) found that the business environment has been changed and as a result the role of management accounting was changed. Regarding the International Federation of Accountants (IFAC), the evolution of the role a management accounting system goes through involves sequential stages. The first stage concerns cost determination and financial control (pre 1950), followed by the information for management planning and control stage (by 1965), the reduction of resource waste in business processes (by 1985), and the final stage is concerned with the creation of value through effective resource use (by 1995), IFAC (1998).

Another dimension is to tackle management accounting discipline emphasised the scope of application of MAPs, the benefit of adoption, and the comparative studies between countries in the adoption of MAPs, (Chenhall \& Langfield-Smith, 1998; Mia, M. \& Abdul Hannan, A., 2005; Drury \& Pettifer, 1993; Ghosh \& Chan, 1997; Forsaith, et al., 2001; France, 2005; Szychta, 2002). In addition, many studies carried out in order to trace the development of management accounting and the history of management accounting, (Spraakman, 1999; Fleischman, Tyson, 2006; Okano, Suzuki, 2006; Näsi, Rohde, 2006; Ahmad B. Abdel- Maksoud, 2004; Strauss 1992; Spraakman, Margret, 2005). Other studies investigated the influence of the external and internal factors on the extent of usage of MAPs, and the benefit of using these practices by using a variety of theories such as an institutional theory, (Hussain \& Gunasekaran, 2002) and a contingency theory (Flacke \& Segbers, 2005; Fry, et al., 1995; Burns, et al., 2004; Ashton, et al., 1995; Silvola, 2005; Haldma \& Laats, 2002; Abdel-Kader \& Luther, 2008; and others. In less-developed countries, Lin and Yu (2002) argued that the application of management accounting remains unsatisfactory. Sulaiman, et al. (2004) indicated the lack of exploratory studies in Asian countries, in addition the need for studies which examine specific factors as to why Asian countries are not adopting newly developed management accounting tools and what the obstacles are to implementing such techniques. In Egypt, as a developing country, a study carried out by Ismail (2007) examined the performance measurement practices within private sector companies in Egypt. The study pointed out that the most significant obstacle inhibiting the adoption of the balanced scorecard is the inadequacy of information systems and added that management's attitude towards non-financial indicators and lack of information may be considered a major obstacle to the adoption of a sophisticated system of performance evaluation.

Triest and Elshahat (2007) indicated the lack of research on MAPs in non-western countries, and that therefore the state of management accounting in these countries was limited. Additionally, the study revealed that the use and sophistication of costing information in Egypt is limited and that no advanced MAPs seem to be applied and the main purpose of the costing system was for pricing decisions rather than performance measurement, process improvement or cost reduction. From the aforementioned research studies, the following research questions can be formulated:

1- What is the present role of management accounting in the Jordanian financial sector?

2- To what extent management accounting practices are used in the Jordanian financial sector?

3- What is the sophistication level of management accounting according to the IFAC model in the Jordanian financial sector?

\section{Research Method}

\subsection{Measurement the Extent of Usage of MAPs}

MAPs will be classified through the current research into five categories: the costing system, budgeting, performance evaluation, decision making and strategic analysis (Abdel-Kader, Luther, 2006). This includes (38) practices which the current research will cover including MAPs both traditional and contemporary, which will provide a significant contribution that will be more objective and convenient by applying the (IFAC) model which is based on classifying the evolution of management accounting and the characteristics of each stage of the evolution (International Federation of Accountants (IFAC), 1998). Conformity with the objectives of the 
research and according to the previous studies which have been carried out to examine MAPs (Abdel-Kader \& Luther, 2006; Adelegan, 2000; Alkizza \&Akbar, 2005; Chenhall \& Langfield-Smith, 1998; Forde, et al., 2005) the current research will ask the respondents to answer the following questions:

1. The degree of usage of each of the practices to find out the extent of usage of each of MAPs, based on a five-point Likert Scale.

2. The importance of each practice to discover the tendency to adopt each of them and how important it is when planning for the future in terms of adopting the practices based on based on three-point Likert Scale.

3. By asking questions to determine the main functions and role of management accounting, a three-point Likert Scale.

4. Asking questions in order to determine which type of management accounting information is important needed the Jordanian financial sector based on a three-point Likert Scale.

\subsection{Measurement the Sophistication Level of MAPs}

The IFAC model classified management accounting practices evaluation into four stages as follows (International Federation of Accountants (IFAC) 1998):

1. Stage one: cost determination and financial control.

2. Stage two: information for management planning and control.

3. Stage three: reduction of resource waste in business processes.

4. Stage four: creation of value through effective resource use.

The aim of this step is to classify the respondent companies according to the IFAC model in order to identify the sophistication level of management accounting practices in the Jordanian financial sector whereas the first stage cost determination and financial control is considered a simple stage and going up to the fourth stage that is named creation of value through effective resource use that is considered as the advanced level, that contains the most sophisticated management accounting practices. In addition, each stage contains practises from the previous stage and the practices that the stage contains, for instance: the second stage contained the practices from the first stage and practices from the second stage, but more emphasis is placed on the practices of the second stage. The third stage contains practices from the first and second stage and the practices of the third sage with more emphasis on the practices of the third stage; the fourth stage contained practices from all the previous stages with more emphasis on the practices of the fourth stage which is the more advanced practices.

In terms of applying the IFAC model, the IFAC model doesn't provide illustrations of precise MAPs which are associated with the particular stages of the evolution of management accounting. The IFAC model was recently adopted by (Abdel-Kader \& Luther, 2006) which attempted to implement the IFAC model and associated the (38) MAPs to each stage of the evolution of management accounting according to the IFAC. The current research has implemented the IFAC model to investigate the level of sophistication of management accounting and follows the (Abdel-Kader \& Luther, 2006) classification of MAPs through the IFAC model for the reason that it is based on reasonable criteria to determine each stage of the evolution of management accounting.

\subsection{Measurement of Organisation Life Cycle Variable}

According to the literature review the corporate life cycle is a significant element in the explanation of the development of all aspects of the firms across the life cycle phases. However, the corporate life cycle perspective has rarely been used in management accounting studies (Moores, Yuen, 2001). In order to employ the organisation life cycle perspective to explain its effect on the respondents' companies and upon the sophistication of management accounting, the current research applied Miller and Friesen's corporate life cycle model that is reported and explained in the literature review chapter (Miller, Friesen, 1984).

Accordingly, the next step after determining the model to be employed regarding the life cycle stages was to determine at which stage of the life cycle stages each of the respondents' companies is located by following the criteria Miller and Friesen adopted to determine at which stage each company is located. Thus, the Miller and Friesen criteria are implemented as the main method to identify each of respondents' stage on the five stage, corporate life cycle where the model, Miller and Friesen (1984). The following criteria were those Miller and Friesen utilised for classification and identification of the organisation life cycle stages and that the current research followed as the main method of classification: 
Table 1. Miller and Friesen (1984)

\begin{tabular}{ll}
\hline Stage & Criteria \\
\hline Birth & Firm is less than 10 years old, has informal structure and is dominated by owner-manager. \\
Growth & Sales growth greater than $15 \%$, functionally organised structure, early formalisation of policies. \\
Mature & Sales growth less than $15 \%$, bureaucratic organisation. \\
Revival & Sales growth greater than $15 \%$, diversification of product lines, use of sophisticated controls and planning systems. \\
Decline & Demand for products levels off, low rate of product innovation, profitability starts to drop off. \\
\hline
\end{tabular}

According to the literature review of the corporate life cycle, and to be consistent with the objectives of the research, each stage has distinct configurations that include: age, structure, strategy, leadership style, and the decision making style (Miller, Friesen, 1984; Moores, Yuen, 2001). Consequently, the research asked questions in terms of each of these configurations to determine at which stage each of the respondents firms is located by utilising the following instruments:

- Use self categorisation measure as some of the studies did, in order to identify the stage at which the respondent company is located, and by asking the respondents to identify their current life cycle stage (Auzair, Langfield-Smith, 2005; Kallunki, Silvola, 2007).

- Use the age of the company, determined through number of years since establishment, and size of the company, determined through number of employees, in order to ascertain and validate the self categorisation that each of respondents understand matches and is consistent with the classification that Miller and Friesen employed (Moores, Yuen, 2001; Miller, Friesen, 1984).

- The current research appended at the beginning of each stage a brief of the main distinctive characteristics of each stage (form of structure, strategy, decision making style and leadership style) in order to assist the respondent to identify the correct stage in which they located their company.

Table 2. Distinctive features of each stage which is used in the self categorisation measure

\begin{tabular}{ll}
\hline Life cycle stage & The distinctive features of each stage \\
\hline Birth & Small firms, Dominated by owner manager, Informal structure, Highly centralised, Considerable \\
& innovation, strategy and substantial risk taking. \\
Growth & Medium firms, Multiple shareholders, Some formalisation of structure, Functional basis of organisation, \\
& Broadening of product market scope into closely related areas, strategy, and rapid growth. \\
Maturity & Large firms, Formal, bureaucratic structure, Functional basis of organisation, Consolidation of product \\
& market, strategy, Focus on efficiently supplying a well-defined market, and slower growth. \\
Revival & Very large firms, Divisional basis of organisation, High differentiation, strategy of product market \\
& diversification movement into some unrelated markets and high risk taking and planning, and rapid \\
& growth. \\
Decline & Market size firms, Formal, bureaucratic structure, Mostly functional basis for organisation, and slower \\
& growth. \\
\hline
\end{tabular}

\section{Research Techniques}

The research utilized a self administration questionnaire in order to identify the current status of MAPs in the Jordanian financial sector. However, the questionnaire method has been used in many management accounting studies. Such as (Chenhall, 2003; Chenhall \& Langfield-Smith, 1998; Cinquini \& Tenucci, 2006; Hutaibat, 2005; Clarke, 1992; Haldma \& Laats, 2002; Moores \& Yuen, 2001; Silvola, 2005). The questionnaire was utilized in order to discover the characteristics of the Jordanian financial sector. The questionnaire contains two parts; the first part was designed to obtain information regarding the companies' characteristics, this section is customary practice in most questionnaire surveys for instance (Davila, Wouters, 2006; Hutaibat, 2005; Cassia, et al., 2005). The second part focused on MAPs particularly in the Jordanian financial sector; therefore, this part consisted of five sections mainly: costing system, budgeting, performance evaluation, decision making, and finally strategic analysis, in this part the questions were adopted from previous empirical studies, for instance (Abdel-Kader, Luther, 2008; Adelegan, 2000; Chan, et al., 1997; Kowalak, 2007; and others).

\subsection{Research Population and Sample}

With reliance on the Ministry of Industry and Trade records at February 2008, the financial sector contains 104 companies divided into four sub-sectors as shown in the following Table 3. 
Table 3. Configurations of research sample

\begin{tabular}{llllll}
\hline Jordanian financial sector & & & & \\
\hline Sub-sectors & Banking & Insurance & Diversified financial services & Real estate & Total \\
\hline Number of companies & 15 & 29 & 27 & 33 & 104 \\
\hline
\end{tabular}

Increasing the size of the sample increases the precision of the sample accordingly and, given the objectives of the current research, the researcher will take the whole population as the sample size. The questionnaire was piloted on a sample containing (8) companies and academic specialists in MAPs were consulted. (95) Questionnaires were distributed to the head of financial accounting of each company. (64) Questionnaires were accredited and valid for analysis which gives (67.3\%) response rate. The table below illustrates the response rate configuration according to the sub-sectors. The Cronbach Alpha test was used in order to test reliability and internal consistency of the questionnaire; accordingly, the internal consistent for the whole questionnaire was examined and revealed to be (0.6496), which is considered as an acceptable internal consistent. The research examined the internal consistent of MAPs, as a results all the groups of practices were revealed to have a satisfactory internal consistent and were reliable and even when examined together, they remained acceptable and with a high internal consistent by (0.9360).

\subsection{Research Hypotheses}

H01: There is no role for management accounting practices in the Jordanian financial sector.

H02: The usage of management accounting practices in the Jordanian financial sector is low.

H03: The sophistication level of management accounting according to the IFAC model in the Jordanian financial sector is low.

\section{Results and Discussions}

\subsection{Demographic Data}

The respondents were classified according to their business type into four main types giving percentages as shown in the figure below.

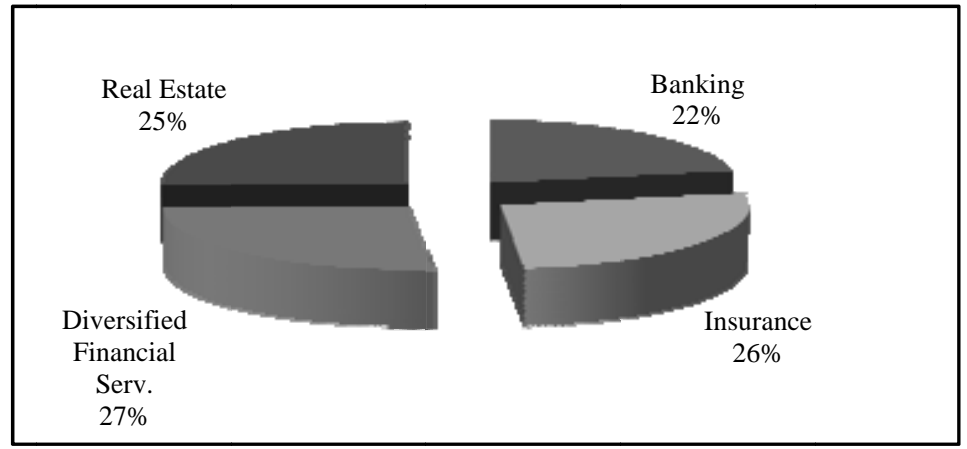

Figure 1. Business type classification

The results indicate that $46.9 \%$ of respondent companies were less than 10 years old. Moreover, $64.1 \%$ of the respondent companies were no older than 15 years old. The results indicate that almost half of the companies in the sample produce/provide less than 10 products/services by $40.6 \%$ and $84.4 \%$ of the respondent companies produce/provide less than 20 products/services. These figures give an obvious indictor to the simplicity of operations which the Jordanian financial sector has produced /provided to their customers. The number of employees question shows that $54.7 \%$ of the respondents answered that they had less than 50 employees, and almost three-quarters of the respondent companies (78.2\%) had less than 300 employees, which is considered to be a small or medium type of business compared with developed countries. In terms of life cycle stages, the result shows that $26.6 \%$ are located in the first stage and $40.6 \%$ in the second stage. This shows that $67.2 \%$ of the respondent companies are located in the first two stages, which supports the interpretation of the previous questions which revealed that the Jordanian financial sector is a youth sector and the results of this question confirm this conclusion. 
The result shows that $26.6 \%$ are located in the first stage and $40.6 \%$ in the second stage. This shows that $67.2 \%$ of the respondent companies are located in the first two stages, which supports the interpretation of the previous questions which revealed that the Jordanian financial sector is a youth sector and the results of this question confirm this conclusion. For more illustration see Table No.4 and Figure 2 below.

Table 4. Classification of companies cross life cycle stages

\begin{tabular}{lll}
\hline Life cycle stages & Frequency & Percentage \\
\hline Birth & 17 & $26.6 \%$ \\
Growth & 26 & $40.6 \%$ \\
Maturity & 17 & $26.6 \%$ \\
Revival & 4 & $6.3 \%$ \\
Total & 64 & $100 \%$ \\
\hline
\end{tabular}

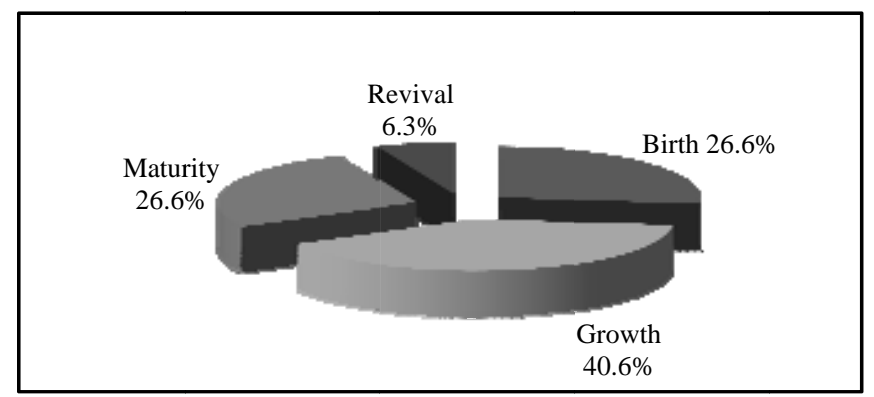

Figure 2. Classification of Jordanian financial sector cross life cycle stages

In addition, the research classified the sub-sectors according to the life cycle stages model, thus, the result show that the banking sub-sector is the oldest sector in terms of the life cycle stage as $64.3 \%$ are located in the maturity stage and $14.3 \%$ in the revival stage. The insurance companies come second in terms of the life cycle stages as $35.3 \%$ are located in the last two stages and most of the diversified financial services companies are located in the second and third stage with $76.5 \%$, and $11.8 \%$ respectively. Finally almost all of the real estate companies have been located in the first stage with $75 \%$. To sum up, the results from these questions gave an indicator to the newly formed companies which have operated in the Jordanian financial sector in terms of their age since $64.1 \%$ of the respondent companies were no older than 15 years, and the simplicity of operations which the Jordanian financial sector has produced /provided to their customers since $84.4 \%$ of the respondent companies produce/provide less than 20 products/services.

The results of the life cycle stages revealed that the Jordanian financial sector is a youth sector since $67.2 \%$ of the respondent companies have been located in the first two stages; moreover, the banking sub-sector is the oldest sector in terms of the life cycle stages, the insurance sector came second in terms of the life cycle stages, then the diversified financial services sector, finally the real estate sector.

\subsection{Role of MAPs}

H01: There is no role for management accounting practices in the Jordanian financial sector.

The results show that $37.5 \%$ of the respondent companies have a specific department called "management accounting", $40.6 \%$ don't have such a department, and finally $21.9 \%$ have the same department but under a different name, therefore, the research shows that $59.4 \%$ of the sample has a specific department for management accounting which reflects the awareness of the management accounting role and tasks, and the diversity of titles which are used by the management accounting department such as financial analysis, strategic planning, and others.

In terms of the importance of the role of management accounting in the Jordanian financial sector, the research revealed that, the most important role was cost determination and financial control followed by information for management planning and control, by 2.66, 2.64 mean score respectively. Regarding, the importance of the type of management accounting is needed, as the research revealed that information addressed directly to the line manager followed by immediate availability upon request, are the most important types by 2.64, 2.62 mean score respectively. 


\subsection{Extent of Usage of MAPs in the Jordanian Financial Sector}

H02: The usage of management accounting practices in the Jordanian financial sector is low.

\subsubsection{Costing System Practices}

The results indicate that the most widespread costing system practice is a separation between variable and fixed cost by $39.1 \%$ often used, $21.9 \%$ moderate used and with 2.92 mean score, followed by using a plant-wide overhead rate (Single predetermined overhead rate used in all departments of a company) by $34.3 \%$ often used and 2.75 mean score. The lowest costing system practices in usage is activity based costing (ABC) since just 11 companies were found often and very often use it, with $11 \%$ often used. The table below gives more illustration of the usage of each of these costing practices.

Table 5. Usage of costing system practices

\begin{tabular}{llllllll}
\hline Usage of costing practices & Mean & S.D & 1 & 2 & 3 & 4 & 5 \\
\hline Separation between variable and fixed cost & 2.92 & 1.337 & 20.2 & 18.8 & 21.9 & 26.6 & 12.5 \\
Using a plant-wide overhead rate & 2.75 & 1.333 & 25 & 18.8 & 21.9 & 25 & 9.3 \\
Using department overhead rates & 2.73 & 1.472 & 32.8 & 10.9 & 20.3 & 21.9 & 14.1 \\
Learning curve techniques & 2.69 & 1.367 & 29.7 & 15.6 & 18.8 & 28.1 & 7.8 \\
The cost of quality & 2.45 & 1.447 & 42.2 & 9.4 & 18.8 & 20.3 & 9.4 \\
Target costs & 2.16 & 0.672 & 10.9 & 67.2 & 17.2 & 4.7 & 0 \\
Activity based cost (ABC) & 1.89 & 1.114 & 53.1 & 17.2 & 18.8 & 9.4 & 1.6 \\
\hline
\end{tabular}

Note: 1- Never, 2- Rarely, 3- Sometimes, 4- Often, 5- Very often.

In terms of the importance of costing system practices, the results indicate that the highest important costing system practice is target cost since it has a 2.23 mean score and $68.8 \%$ considered it as important. Using a plant-wide overhead rate was ranked to be the second highest usage practice, but in terms of the importance it is revealed to be the lowest practice by a 1.91 mean score. The research concludes that there is a trend in the future within the Jordanian financial sector to adopt contemporary costing practices, for instance target costs practice, with the continued existence of some of conventional practices, for instance separation between variable and fixed cost practice. Moreover, there are some practices that might well be extinct in the future such as ABC because it is classified as low usage and low importance.

The research is consistent with the previous studies that there is a lack in adopting the contemporary costing system practices in developing countries comparing with developed countries such as (Abdel-Kader \& Luther, 2006; Lamminmaki \& Drury, 2001; Cinquini \& Tenucci ,2006; Al-Omiri \& Drury, 2007).

\subsubsection{Budgeting Practices}

The results reveal that $78.1 \%$ of respondents are using budgeting practice for planning, which is considered to be one of the highest MAPs usage in general and among budgeting practices in particular. Using budgeting for controlling costs came as the second most used budgeting practice as it occurred $76.5 \%$ and the two lowest budgeting practices are activity based budgeting and zero-based budgeting by $40.7 \%$, and $1.6 \%$ respectively.

Moreover, the table reviews the budgeting practices according to their ranking in terms of their extent of usage from the highest to the lowest practice, based on the mean score as the conventional budgeting practices are more frequently used, compared with the contemporary budgeting practices such as activity based budgeting, nevertheless the research revealed that the budgeting practices are the most used among the whole MAPs as the budgeting for planning, budgeting for controlling costs, budgeting for long term (strategic) plans, and flexible budgeting have recorded the highest scores.

Using the table the research concludes that budgeting practices are heavily used in the Jordanian financial sector specially the banking sub-sector. Therefore, the research is consisted with a number of studies that examined the budgeting practices, Such as Ghosh and Chan (1997), Joshi, (2001), Burnett et al. (2005).

Regarding the importance of the budgeting practices, the results show that budgeting for planning, budgeting for controlling costs, and budgeting for long term (strategic) plans were ranked to be the highest in terms of importance since they achieved $70.3 \%, 62.5 \%$, and $59.4 \%$ respectively. Zero-based budgeting practices have been ranked to be the lowest usage, and once again it has been ranked to be the lowest practice in terms of the importance, in other words, since zero-based budgeting is ranked the lowest in both of the questions that means this practice would not be adopted in the future. Budgeting with "what if analysis" practice has been ranked as 
less important by 2.14 mean score where in terms of usage it has been ranked a high used practice; therefore, this practice could stop being used in the future.

Table 6. Usage of budgeting practices

\begin{tabular}{llllllll}
\hline Usage of budgeting practices & Mean & S.D & 1 & 2 & 3 & 4 & 5 \\
\hline Budgeting for planning & 3.97 & 1.195 & 6.3 & 9.4 & 6.3 & 37.5 & 40.6 \\
Budgeting for controlling costs & 3.95 & 1.201 & 6.3 & 9.4 & 7.8 & 35.9 & 40.6 \\
Budgeting for long term (strategic) plans & 3.64 & 1.289 & 10.9 & 6.3 & 21.9 & 29.7 & 31.3 \\
Flexible budgeting & 3.31 & 1.283 & 14.1 & 10.9 & 21.9 & 35.9 & 17.2 \\
Budgeting with "what if analysis” & 3.12 & 1.351 & 17.2 & 14.1 & 26.6 & 23.4 & 18.8 \\
Activity based budgeting & 2.73 & 1.493 & 31.3 & 18.8 & 9.4 & 26.6 & 14.1 \\
Zero -based budgeting & 1.52 & .816 & 67.2 & 15.6 & 15.6 & 1.6 & 0 \\
\hline
\end{tabular}

Note: 1- Never, 2- Rarely, 3- Sometimes, 4- Often, 5- Very often.

\subsubsection{Performance Evaluation Practices}

Respondents rated the financial measures as the highest practice which is utilized in their companies since $78.1 \%$ of respondents ranked it often and very often used, however, financial measures is classified as one of the traditional MAPs. According to the table below there is moderate usage of the non-financial measures related to operations and innovation, as $64.7 \%$ of respondents answered they often and very often used it. Unsurprisingly the first question revealed that there is a lack of use of non-financial measures which they considered as contemporary MAPs as $26.6 \%$ of respondents said they never or rarely used non-financial measures related to customers and just $29.7 \%$ reported they often or very often used this practice.

Non-financial measures related to employees practice were found to be little used in the Jordanian financial sector where $48.4 \%$ of respondents said they were never or rarely used. Non-financial measures related to employees practice, only $18.7 \%$ of respondents rated this practice as often or very often used. According to respondents answers, economic value added or residual income practice was found to be little used in the Jordanian financial sector since $56.3 \%$ of respondents ranked it never or rarely used. Economic value added or residual income, no more than $20.3 \%$ reported they often or very often used this practice. Finally, benchmarks are considered as one of the most contemporary MAPs and rarely used. The research found that $67.2 \%$ of respondents rated benchmarks as never or rarely used in the Jordanian.

Table 7. Usage of performance evaluation practices

\begin{tabular}{llllllll}
\hline Usage of performance evaluation practices & Mean & S.D & 1 & 2 & 3 & 4 & 5 \\
\hline Financial measures & 4.25 & .959 & 1.6 & 3.1 & 17.2 & 25 & 53.1 \\
Non-financial measures related to operations and innovation & 3.48 & 1.168 & 7.8 & 10.9 & 26.6 & 34.4 & 20.3 \\
Non-financial measures related to customers & 3.08 & 1.131 & 9.4 & 17.2 & 43.8 & 15.6 & 14.1 \\
Non-financial measures related to employees & 2.53 & 1.284 & 28.1 & 20.3 & 32.8 & 7.8 & 10.9 \\
Economic value added or residual income & 2.38 & 1.175 & 29.7 & 26.6 & 23.4 & 17.2 & 3.1 \\
Benchmarks & 2.22 & 1.303 & 39.1 & 28.1 & 12.5 & 12.5 & 7.8 \\
\hline
\end{tabular}

Note: 1- Never, 2- Rarely, 3- Sometimes, 4- Often, 5- Very often.

Moving to the second question in this section which asked the respondents to rate the importance of the performance evaluation practice, the research found that almost all respondents considered all of the performance evaluation practices as important, even the contemporary practice, which gives a strong indication of the future trend of these companies which might adopt these practices, since $73.4 \%$ of respondents rated the financial measures practice as important, $42.2 \%$ rated the non-financial measures related to customers practice as important. Non-financial measures related to operations and innovation practice, non-financial measures related to employees practice, benchmarks practice, and economic value added or residual income practice were rated as important performance evaluation practices by $37.5 \%, 35.9 \%, 26.6 \%$ and $29.7 \%$ respectively, where these practices have not been adopted widely, therefore based on these figures the research could predict that the respondent companies intend to adopt these practices in the future.

There are many studies which have been carried out to examine the level of adoption of performance evaluation practices and the majority of these studies emphasised the significant role of these practices in the companies and revealed that these practices are widely used in developing countries especially non-financial measures. For instance; Wijewardena, De Zoysa (1998), Haldma \& Laats (2002), Hyvonen (2005), and Cinquini, Tenucci 
(2006). Unsurprisingly the research revealed that there is a lack of use of non-financial measures that they considered as contemporary management accounting practices as $26.6 \%$ of respondents said they never or rarely used non-financial measures related to customers and just $29.7 \%$ reported they often or very often used this practice.

The research indicated that there is a lack of use of non-financial measures that are considered as contemporary management accounting practices, and the financial measures were considered as the highest practice being utilised in the Jordanian financial sector, i.e. they were classified as one of the traditional management accounting practices. However, based on the analysis of the importance of contemporary practices, the research predicted that companies intend to adopt these practices in the future.

\subsubsection{Decision Making Practices}

In terms of the extent of usage of the decision making practices in the Jordanian financial sector, the research revealed that product profitability analysis has the highest rate of usage since $65.6 \%$ of respondents were found used it often and very often, followed by cost- value- profit analysis (break- even analysis) by 59.4\% of respondents who used it often and very often and discounted cash flow methods for evaluation the capital investment were used by 59.4\%. Payback period and /or accounting rate of return practice was found to be used by $54.7 \%$ with often and very often answered, followed by stock control models practices which are reported to be used often and very often by $40.6 \%$ of respondents. The last five of the ten practices as shown in the table below, were rated to be low usage practices, since $34.4 \%$ of respondents were found to have never and rarely used product profitability analysis and $39.1 \%$ of them used it sometimes.

Likewise, the last four practices found were found to have low adoption in the Jordanian financial sector, where $39.1 \%$ of respondents reported that they never and rarely used cost of capital in discounting cash flow for major capital investment evaluation, $45.4 \%$ of respondents were found never or rarely used performing sensitivity "what if analysis" for evaluating major capital investment projects, 38.4\% reported they never or rarely used probability analysis or computer simulation for evaluation of the risk of major capital investment projects, and finally $61 \%$ of respondents reported that they never or rarely used non- financial aspects that are documented and reported for the evaluation of major capital investment. See the table below for more information.

Table 8. Usage of decision making practices

\begin{tabular}{llllllll}
\hline Usage of decision making practices & Mean & S.D & 1 & 2 & 3 & 4 & 5 \\
\hline Product profitability analysis & 3.81 & 1.125 & 4.7 & 7.8 & 21.9 & 32.8 & 32.8 \\
Cost- value- profit analysis (break- even analysis ) & 3.64 & 1.277 & 10.9 & 4.7 & 25 & 28.1 & 31.3 \\
Cash flow methods & 3.61 & 1.177 & 7.8 & 7.8 & 25 & 34.4 & 25 \\
Payback period and /or accounting rate of return & 3.52 & 1.208 & 9.4 & 7.8 & 28.1 & 31.3 & 23.4 \\
Stock control models & 2.95 & 1.430 & 23.4 & 15.6 & 20.3 & 23.4 & 17.2 \\
Customer profitability analysis & 2.86 & 1.207 & 17.2 & 17.2 & 39.1 & 15.6 & 10.9 \\
Calculation and use of cost of capital in discounting cash flow & 2.73 & 1.312 & 26.6 & 12.5 & 31.3 & 20.3 & 9.4 \\
Performing sensitivity “what if analysis" & 2.58 & 1.232 & 26.6 & 18.8 & 31.3 & 17.2 & 6.3 \\
Probability analysis or computer simulation & 2.52 & 1.403 & 37.5 & 10.9 & 23.4 & 18.8 & 9.4 \\
Non-financial aspects are documented and reported & 2.19 & 1.082 & 34.4 & 26.6 & 26.6 & 10.9 & 1.6 \\
\hline
\end{tabular}

Note: 1- Never, 2- Rarely, 3- Sometimes, 4- Often, 5- Very often.

In terms of the importance of the decision making practices, the results show that the first five practices have been rated to be the most used practices. Once again they are rated to be the most important and the last five practices which rated low usage, ranked low importance to the Jordanian financial sector, which leads to the conclusion that the first five practices would be the most widespread practices in the Jordanian financial sector and the last five practices didn't provide any indication that they would be used in the future more frequently. In general, the research revealed that there is a lack of usage of decision making practices and strategic analysis practices in the Jordanian financial sector. The results in this section consist with earlier studies that examined the usage and the importance of the ten decision making practices in terms of broadly usage of decision making practices in developing countries. Such as, Forde, Burnett et al.( 2005), France ( 2005), and Forsaith, Tilt et al. (2001).

\subsubsection{Strategic Analysis Practices}

This section contains modern management accounting which provides information for strategic analysis; therefore this part will cover eight strategic analysis practices which are listed in the table below. The results 
shows that there is a lack of usage of the strategic analysis practices which appeared obvious regarding the figures in the table below since the long-range forecasting practice is reported as high usage practice with $63 \%$ of the respondent companies rating it as often or very often used. After this comes the shareholder value practice which could be classified as a moderate used practice since $31.3 \%$ of the respondents rated it as often and very often used, but all the last six practices have been rated as little used in the Jordanian financial sector as the following; $43.8 \%$ of the respondents have reported never or rarely used analysis of competitive position practice, and $54.7 \%$ of respondents ranked the value chain analysis practice by never or rarely used.

Analysis of competitors (strengths and weaknesses) practice was rated never and rarely used by $54.7 \%$ of the respondents, $18.8 \%$ of respondents have reported used often and very often the industry analysis practice, $11.5 \%$ of the respondents have reported often and very often used the possibilities of integration with suppliers and / or customers and / or value chains practice. According to the results of the first question, the research revealed that there is low adoption and usage of strategic analysis practices in the Jordanian financial sector, whilst for the last six practices almost half of the respondents rated them as never or rarely used. See the table below.

Table 9. Usage of strategic analysis practices

\begin{tabular}{llllllll}
\hline Usage of strategic analysis practices & Mean & S.D & 1 & 2 & 3 & 4 & 5 \\
\hline Long-range forecasting & 3.70 & 1.079 & 4.7 & 7.8 & 25 & 37.5 & 25 \\
Shareholder value & 2.77 & 1.218 & 23.4 & 12.5 & 32.8 & 26.6 & 4.7 \\
Analysis of competitive position & 2.70 & 1.318 & 26.6 & 17.2 & 23.4 & 25 & 7.8 \\
Value chain analysis & 2.48 & 1.182 & 23.4 & 31.3 & 25 & 14.1 & 6.3 \\
Analysis of competitors; strengths and weaknesses & 2.44 & 1.308 & 32.8 & 21.9 & 21.9 & 15.6 & 7.8 \\
Industry analysis & 2.31 & 1.283 & 39.1 & 15.6 & 26.6 & 12.5 & 6.3 \\
Value chains & 2.17 & 1.092 & 32.8 & 32.8 & 21.9 & 9.4 & 3.1 \\
Product life cycle analysis & 2.09 & 1.094 & 39.1 & 26.6 & 21.9 & 10.9 & 1.6 \\
\hline
\end{tabular}

Note: 1- Never, 2- Rarely, 3- Sometimes, 4- Often, 5- Very often.

According to the analysis of the importance of these practices, the research found that the practices which were ranked to be the often and very often used are the same practices which were ranked to be important to the respondent companies, and likewise to the other practice which was rated to be less used, they ranked to be less important as well. Therefore, the research revealed that there would not be any changes in the future in terms of adopting new strategic analysis practices. In general, the research revealed product profitability analysis has the highest rate of usage among the decision making practices and long-range forecasting practice is reported as the highest usage practice among strategic analysis practices. The results contrast with some studies that have been carried out in terms of examining the extent of usage of strategic analysis practice, for instance, Chenhall and Langfield-Smith (1998), Hyvonen (2005), Abdel-Kader and Luther (2006).

\subsection{Sophistication Level of MAPs in the Jordanian Financial Sector}

H03: The sophistication level of management accounting according to the IFAC model in the Jordanian financial sector is low.

In order to identify the sophistication level of management accounting according to the IFAC model, the research followed the study carried by Abdel-Kader and Luther (2006). The identification aim is carried out through several steps, starting with determining the characteristics of each of the IFAC model stage, the next step is to find out the mean of each of these stages for all respondent companies in order to find out in which of the IFAC stage each company is placed based on the practices which are used in each of these companies. This is followed by labelling each respondent company according to the IFAC characteristics, where the companies matched the practices which belong to the first stage; they were labelled to the first stage and measured with this criterion against all of the companies. For instance, the company which gives 2 mean score in the first stage, 3.25 mean score in the second stage, 1.29 mean score in the third stage and 2.07 mean score in the fourth stage, is labelled as being in the second stage and all others are labelled by the same method.

Accordingly, the research found that almost all of the sample population are located in the first stage with $64.1 \%$, the second stage is revealed to be $29.7 \%$ from the whole sample population, and finally the last two stages which are considered as the more sophisticated stages found a very low number of companies located in this stage with $3.1 \%$ for each. According to these figures, the research concluded that the Jordanian financial sector is dependent on the traditional MAPs and almost all of the whole sample population are implementing MAPs which provided information for cost determination and financial control and information for management planning and control. 
In other words, the traditional MAPs are still widespread and highly used in the Jordanian financial sector and they are rarely using the more sophisticated or advanced MAPs, for more information see the table and figure below.

Table 10. Classification of the Jordanian financial sector based on the IFAC Model

\begin{tabular}{llll}
\hline Stage & IFAC model stages & Frequency & Percentage \\
\hline One & Cost determination and financial control & 41 & $64.1 \%$ \\
Two & Information for management planning and control & 19 & $29.7 \%$ \\
Three & Reduction of resource waste in business processes & 2 & $3.1 \%$ \\
Four & Creation of value through effective resource use & 2 & $3.1 \%$ \\
Total & & 64 & $100 \%$ \\
\hline
\end{tabular}

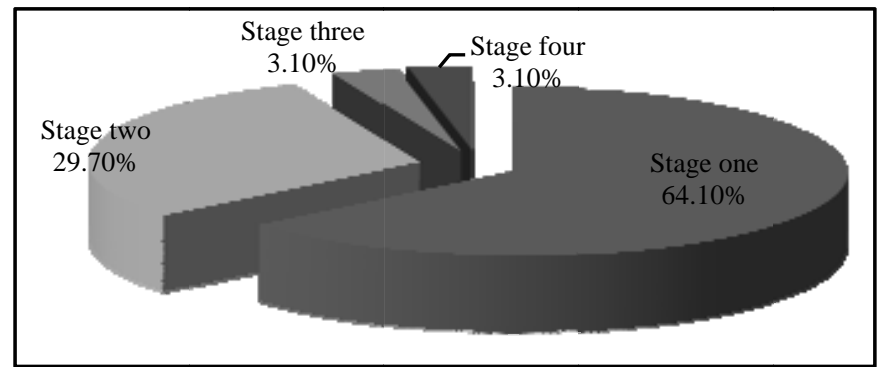

Figure 3. The Jordanian financial sector based on the IFAC Model

\subsection{Further Discussion}

Based on the information regarding the importance of each of the MAPs, the research repeated the same steps to find the location of MAPs in the Jordanian financial sector according to the IFAC model stages. Therefore, as shown in the table below, there is a slight movement from stage one to stage two as in the last analysis the proportion in stage one is revealed to be $64.1 \%$, but according to this analysis it is revealed to be $39 \%$ and stage two in the previous analysis was found to be $29.7 \%$, but in this analysis was found to be $28 \%$.

Interestingly, stage three and stage four according to the previous analysis were indicated to be a very low number of companies, but according to the current analysis there is a remarkable increase in the number of companies now located in the third and fourth stage which, once again they considered as more sophisticated levels by $17.4 \%$ and $15.6 \%$. To sum up, this analysis indicated that in the future phase there would be an improvement in terms of the adoption of more sophisticated or advance MAPs in the Jordanian financial sector which provide information regarding the reduction of resource waste in business processes and for creation of value through effective resource use. See the table below for more illustration.

Table 11. The IFAC model and the importance of MAPs

\begin{tabular}{llll}
\hline Stage & IFAC stages & Frequency & percentage \\
\hline One & Cost determination and financial control & 25 & $39 \%$ \\
Two & Information for management planning and control & 18 & $28 \%$ \\
Three & Reduction of resource waste in business processes & 11 & $17.4 \%$ \\
Four & Creation of value through effective resource use & 10 & $15.6 \%$ \\
Total & & 64 & $100 \%$ \\
\hline
\end{tabular}

It is worthwhile examining the classification of the IFAC model stages across the life cycle stages, as shown in the analysis of section two, that the 64 companies divided into four life cycle stages, and according to the tables below the research revealed several results; firstly the birth life cycle stage companies are almost all located in stage one and two based on the IFAC model by $94 \%$ which is a reasonable conclusion as the birth life cycle stage is characterized to be less sophisticated in terms of operation and less amount of information is needed, and the emphasis is placed on cost determination and financial control and information for management planning and control. Secondly, the growth life cycle stage was found to have moved a little to adoption of the practices with emphasis on reduction of resource waste in business processes (stage three of IFAC) by $4 \%$.Thirdly, the maturity life cycle stage was found to move from the first IFAC stage into the second stage with a small move into the third stage since the stage one occurred $47 \%$, stage two reported by $47 \%$, and finally stage three by $6 \%$. Finally, 
the revival life cycle stage, reported an adoption of practices from stage four of the IFAC model by $25 \%$. In general the research revealed that the adoption of MAPs move from stage one of the IFAC model into the following stages during the respondents companies move from the life cycle stage to another, which gives an initial conclusion that the sophistication of MAPs in the Jordanian financial sector is associated positively with the life cycle stages variable.

Table 12. The IFAC model and life cycle stage stages

\begin{tabular}{llllll}
\hline \multirow{2}{*}{ Stages } & \multirow{2}{*}{ IFAC stages } & \multicolumn{3}{c}{ Life cycle stages } \\
\cline { 3 - 5 } & & Birth & Growth & Maturity & Revival \\
\hline Stage 1 & Cost determination and financial control & $65 \%$ & $77 \%$ & $47 \%$ & $50 \%$ \\
Stage 2 & Information for management planning and control & $29 \%$ & $19 \%$ & $47 \%$ & $25 \%$ \\
Stage 3 & Reduction of resource waste in business processes & 0 & $4 \%$ & $6 \%$ & 0 \\
Stage 4 & Creation of value through effective resources use & $6 \%$ & 0 & 0 & $25 \%$ \\
\hline
\end{tabular}

Similarly, the research attempts to find out the classification of the IFAC model stages according to the classification of the Jordanian financial sector which includes four main sub-sectors; banking, insurance, financial diversified services, and real estate. According to the tables below the research found that the banking sub-sector is the more sophisticated in terms of the adoption of MAPs, since the banking respondents reported $7 \%$ located in stage four of the IFAC stages and $50 \%$ in stage two of the IFAC model. The financial diversified services sub-sector comes after the banking in terms the sophistication level of MAPs based on the IFAC model, since $6 \%$ are located in stage four of the IFAC, $6 \%$ in stage three, $18 \%$ in stage two, and finally the rest are located in stage one of the IFAC model. These are followed by the insurance sub-sector in terms of the sophistication with 31\% located in stage two of the IFAC and the rest located in stage one of the IFAC model. Finally, the real estate sub-sector is revealed to be the lowest sub-sector in terms of the sophistication level of MAPs, where almost all of the respondent companies are located in stage one and two of the IFAC model by $94 \%$.

Table 13. The IFAC model and sector classification

\begin{tabular}{|c|c|c|c|c|c|}
\hline \multirow{2}{*}{ Stages } & \multirow{2}{*}{ IFAC stages } & \multicolumn{4}{|c|}{ Jordanian financial sector } \\
\hline & & Banking & Insurance & Financial serv. & Real estate \\
\hline Stage 1 & Cost determination and financial control & $43 \%$ & $69 \%$ & $71 \%$ & $71 \%$ \\
\hline Stage 2 & Information for management planning and control & $50 \%$ & $31 \%$ & $18 \%$ & $23 \%$ \\
\hline Stage 3 & Reduction of resource waste in business processes & 0 & 0 & $6 \%$ & $6 \%$ \\
\hline Stage 4 & Creation of value through effective resources use & $7 \%$ & 0 & $6 \%$ & 0 \\
\hline
\end{tabular}

\section{Conclusions}

In terms of the distinct features of the Jordanian financial sector, the research indicated the newly formed companies which have operated in the Jordanian financial sector in terms of their age, net sale growth, number of employees, as $64.1 \%$ of the respondent companies were no older than 15 years, $46.9 \%$ have less than $5 \%$ net sale growth, and (78.2\%) had less than 300 employees. In addition, the research revealed that $26.6 \%$ of the Jordanian financial sector companies are located in the first stage and $40.6 \%$ in the second stage. This shows that $67.2 \%$ of the respondent companies are located in the first two stages, which support the point above which revealed that the Jordanian financial sector is a youth sector.

The findings of the research reported that within the Jordanian financial sector traditional MAPs are still widespread and highly used, rarely using the more sophisticated or advanced MAPs, and there is a diversity of MAPs are used in the financial sector context. Budgeting practices and financial measures are heavily used in the Jordanian financial sector. Activity Based Costing (ABC) was ranked the lowest used practice among the costing practices. In general, the research revealed that there is a lack of usage of decision making practices and strategic analysis practices in the Jordanian financial sector. Furthermore, the research predicted that some practices will be used in the future, for instance; target costing, industry analysis practice, and benchmarks practice, and predicted the practices would that be prevalently used namely; financial measures practice and budgeting for planning practice. The research predicted that some practices might become extinct from use, such as, product life cycle analysis practice and $\mathrm{ABC}$ practice. 
The research revealed that almost all of the Jordanian financial sector companies are implementing MAPs which provide information for cost determination and financial control and information for management planning and control, whereas $64.1 \%$ of the companies are located in the first stage, $29.7 \%$ in the second stage based on the IFAC model, which indicates the simplicity of information that they require, which in turn reflects the simplicity of MAPs that are used in the Jordanian financial sector. Regarding the sophistication level of MAPs, the research predicted that in the future there would be an improvement in terms of the adoption of more sophisticated or advanced MAPs in the Jordanian financial sector which provide information regarding the reduction of resource waste in business processes and for the creation of value through effective resource use. Whereas based on the IFAC model, the research revealed that $39 \%$ of the companies are located in the first stage, $28 \%$ in the second stage, $17.4 \%$ in the third stage, and $15.6 \%$ were found located in the fourth stage.

As a conclusion, the research is consistent with previous studies which indicated that traditional MAPs are still widely used, there is a lack of using MAPs in the developing countries, and indicated the improvement which would take place in the Jordanian financial sector in terms of the adoption of more sophisticated or advance MAPs. In addition, the financial sector is a crucial sector that has a significant impact on the economy, and requires accurate and timely information. Consequently, the research encourages the companies to adopt advanced MAPs, particularly decision making practices and strategic analysis practices, since the research revealed there is a lack of adoption of these practices. Finally, the current research is considered to be a platform and a starting point for future research into the management accounting in the Jordanian financial sector.

\section{Limitations and Future Research}

As the results show that the Jordanian financial sector is a youth sector. Future research is needed to show the time period required to progress through the last two stages. This research depends on the questionnaire as a method to collect the relevant data which is not free of bias. Therefore, future research should employ other techniques such as interviews to reveal rich information about management accounting practices. In addition, this research is cross sectional which reflects the current status of management accounting practices but is neither before nor after. Thus, longitudinal research is needed to proof the current research assumptions.

\section{References}

Abdel-Kader, M., \& Luther, R. (2006). Management accounting practices in the British food and drinks industry. British Food Journal, 108(5), 336-357. http://dx.doi.org/10.1108/00070700610661321

Abdel-Kader, M., \& Luther, R. (2008). The impact of firm characteristics on management accounting practices: A UK-based empirical analysis. British Accounting Review, 40(1), 2-27. http://dx.doi.org/10.1016/j.bar.2007.11.003

Abdel-Maksoud, A. B. (2004). Manufacturing in the UK: contemporary characteristics and performances indicators. Journal of manufacturing technological management, 15(2), 155-171.

Adelegan, O. J. (2000). Management accounting practices in Nigerian companies. Working paper, University of Ibaden, Nigeria.

Alkizza, A., \& Akbar, S. (2005). The impact of business environment on management accounting practices: Libyan evidence. working paper, University of Liverpool, Liverpool.

Ashton, D., Hopper, T., \& Scapens, R. (1995). The changing nature of issues in management accounting. London: Prentice Hall.

Billings, M., \& Capie, F. (2004). The development of management accounting in UK clearing banks, 1920-70. $\begin{array}{lllll}\text { Accounting Business and } & \text { Financial }\end{array}$ http://dx.doi.org/10.1080/0958520042000277793

Burns, J., Hopper, T., \& Yazdifar, H. (2004). Management accounting education and training: putting management in and taking accounting out. Qualitative Research in Accounting \& Management, 1(1), 1-29. http://dx.doi.org/10.1108/11766090410816271

Carmona, S. (2006). The history of management accounting in France, Italy, Portugal, and Spain. In Chapman, S. et al, (Eds.), Handbooks of Management Accounting Research (pp. 905-922). London: Elsevier. http://dx.doi.org/10.1016/S1751-3243(06)02018-9

Cassia, L., Paleari, S., \& Redondi, R. (2005). Management accounting systems and organisational structure. Small Business Economics, 25(4), 373-391. http://dx.doi.org/10.1007/s11187-004-6494-8 
Chan, A. M. Y., Chan, N. P. M., \& Lui, K. K. (1997). Management accounting practices and market performance of the Chinese listed companies. Asian-Pacific Conference on International Accounting Issues, 9, 171-173.

Chenhall, R. H. (2003). Management control systems design within its organizational context: findings from contingency-based research and directions for the future. Accounting Organisations and Society, 28(2-3), 127-168. http://dx.doi.org/10.1016/S0361-3682(01)00027-7

Chenhall, R. H., \& Langfield-Smith, K. (1998). Adoption and benefits of management accounting practices: an Australian study. Management Accounting Research, 9(1), 1-20. http://dx.doi.org/10.1006/mare.1997.0060

Cinquini, L., \& Tenucci, A. (2006). Strategic management accounting: Exploring distinctive features and links with strategy. Available at: http://mpra.ub.uni-muenchen.de/212/ edn. Munich Personal RePEc Archive, (accessed 15 May 2008).

Clarke, P. J. (1992). Management accounting practices in Irish manufacturing businesses: A pilot study. Proceedings of the Annual Conference- Irish Accounting and Finance Association (5th), pp. 17-34.

Davila, A., \& Foster, G. (2005). Management accounting systems adoption decisions: Evidence and performance implications from early-stage/startup companies. Accounting Review, 80(4), 1039-1068. http://dx.doi.org/10.2308/accr.2005.80.4.1039

Davila, T., \& Wouters, M. (2006). Management accounting in the manufacturing sector: Managing costs at the design and production stages. In Chapman, S. et al. (Eds.), Handbooks of Management Accounting Research (pp. 831-858). London: Elsevier. http://dx.doi.org/10.1016/S1751-3243(06)02015-3

Drury, C., \& Pettifer, D. (1993). Management accounting practices in building societies. Management Accounting, 71(3), 36.

Ewert, R., \& Wagenhofer, A. (2006). Management accounting theory andpractice in German-speaking countries. In Chapman, S. et al. (Eds.), Handbooks of Management Accounting Research (pp. 1035-1069). London: Elsevier. http://dx.doi.org/10.1016/S1751-3243(06)02021-9

Ezzamel, M. (1994). Organizational change and accounting: understanding the budgeting system in its organizational context. Organization Studies -Berlin- European Group for Organizational Studies, 15(2), 213. http://dx.doi.org/10.1177/017084069401500203

Ezzamel, M., Lilley, S., \& Willmott, H. (1997). Accounting for management and managing accounting: reflections on recent changes in the UK. Journal of Management Studies, 34(3), 439-464. http://dx.doi.org/10.1111/1467-6486.00058

Flacke, K., \& Segbers, K. (2005). Does management accounting follow entrepreneurial characteristics? Results of an empirical analysis of German SME. Working paper, Arbeitapapier edn, University Of Munster, Germany.

Fleischman, R., \& Tyson, T. (2006). The history of management accounting in the U.S. In Chapman, S. et al. (Eds.), Handbooks of Management Accounting Research (pp. 1071-1089). London: Elsevier. http://dx.doi.org/10.1016/S1751-3243(06)02022-0

Forde, E. D., Burnett, J., \& Devonish, D. (2005). A pilot study on management accounting practices by Caribbean business. working paper ,University of the West Indies, Jamaica.

Forsaith, D., Tilt, C., \& Xydias-lobo, M. (2001). The future of management accounting: a South Australian perspective. working paper, School of Commerce, pp. 1-20.

France, A. (2005). An alternative approach to surveying management accounting practices. working paper, Waikato Institute of Technology, New Zealand.

Fry, T. D., Steele, D. C., \& Saladin, B. A. (1995). The role of management accounting in the development of a manufacturing strategy. International Journal of Operations and Production Management, 15(12), 21-31. http://dx.doi.org/10.1108/01443579510104475

Garg, A., Ghosh, D., \& Halper, H. (2004). Best practices in management accounting. Journal of Cost Management, 18(2), 21-25.

Garg, A., Ghosh, D., Hudick, J., \& Nowacki, C. (2003). Roles and practices in management accounting today. Strategic Finance, 85(1), 30-35.

Ghosh, B. C., \& Chan, Y. (1997). Management accounting in Singapore - well in place?. Managerial Auditing Journal, 12(1), 16-18. http://dx.doi.org/10.1108/02686909710155966 
Gupta, K. M., \& Gunasekaran, A. (2005). Costing in new enterprise environment: A challenge for managerial accounting researchers and practitioners. Managerial Auditing Journal, 20(4), 337-353. http://dx.doi.org/10.1108/02686900510592034

Gutierrez, F., Larrinaga, C., \& Nunez, M. (2005). Cost and management accounting in pre-industrial revolution Spain. Accounting Historians Journal, 32(1), 111-148.

Haldma, T., \& Laats, K. (2002). Contingencies influencing the management accounting practices of Estonian manufacturing companies. Management Accounting Research, 13(4), 379-400. http://dx.doi.org/10.1006/mare.2002.0197

Heidmann, M., Schaffer, U., \& Strahringer, S. (2008). Exploring the Role of Management Accounting Systems in Strategic Sensemaking. Information Systems Management, 25(3), 244-257. http://dx.doi.org/10.1080/10580530802151194

Hopper, T. (1999). Postcard from Japan: a management accounting view. Accounting Auditing and Accountability Journal, 12(1), 58-68. http://dx.doi.org/10.1108/09513579910259924

Hussain, M. M., \& Gunasekaran, A. (2002). An institutional perspective of non-financial management accounting measures: a review of the financial services industry. Managerial Auditing Journal, 17(9), 518-536. http://dx.doi.org/10.1108/02686900210447524

Hutaibat, K. A. (2005). Management accounting practices in Jordan - a contingency approach. (PhD Dissertation). University of Bristol, Bristol.

Hyvonen, J. (2005). Adoption and benefits of management accounting systems: Evidence from Finland and $\begin{array}{llll}\text { Australia. Advances in International Accounting, } & \text { 18, }\end{array}$ http://dx.doi.org/10.1016/S0897-3660(05)18005-2

International Federation of Accountants. (1998). International Management Accounting Practice Statement: management Accounting Concepts. New York, NY.

Islam, M., \& Kantor, J. (2005). The development of quality management accounting practices in China. Managerial Auditing Journal, 20(7), 707-724. http://dx.doi.org/10.1108/02686900510611249

Ismail, T. H. (2007). Performance evaluation measures in the private sector: Egyptian practice. Managerial Auditing Journal, 22(5), 503-513. http://dx.doi.org/10.1108/02686900710750775

Jazayeri, M., \& Cuthbert, P. (2004). Research in management accounting: What needs to be researched?. working paper, Department of Business and Management Studies, Manchester Metropolitan University. Manchester.

Johnson, H. T., \& Kaplan, R. (1987). The relevance lost: the rise and fall of management accounting. Working Paper, Mass.: Harvard Business School, Boston.

Joshi, P. L. (2001). The international diffusion of new management accounting practices: the case of India. Journal of International Accounting Auditing and Taxation, 10(1), 85-109. http://dx.doi.org/10.1016/S1061-9518(01)00037-4

Kaplan, R. (1984). The evolution of management accounting. Accounting Review, July, 390-396.

Kattan, F., Pike, R., \& Tayles, M. (2007). Reliance on management accounting under environmental uncertainty: The case of Palestine. Journal of Accounting and Organizational Change, 3(3), 227-249. http://dx.doi.org/10.1108/18325910710820283

Kowalak, R. (2007). Implementation of best practices in management accounting. working paper, Prace Naukowe- Akademii Ekonomicznej Imienia Oskara Langego we Wroclawiu, (1178), pp. 63-69.

Lamminmaki, D., \& Drury, C. (2001). A comparison of New Zealand and British product-costing practices. International Journal of Accounting, 36(3), 329-347. http://dx.doi.org/10.1016/S0020-7063(01)00106-6

Lexa, F., Mehta, T., \& Seidmann, A. (2005). Managerial accounting applications in radiology. Journal of the American College of Radiology, 2(3), 262-270. http://dx.doi.org/10.1016/j.jacr.2004.08.020

Lin, Z. J., \& Yu, Z. (2002). Responsibility cost control system in China: the Han Dan experience. Asia Pacific Business Review, 9(1), 59-78. http://dx.doi.org/10.1080/713999171

Lobo, A., Escobar, B., \& González, M. (2008). Organizational control System in a continuous improvement environment: Special reference to the role of management accounting. Journal of Accounting - Business \& Management, 15, 1-32. 
Mathejka, M., \& Waegenaere, A. (1999). Organizational design and management accounting change. working paper, Center Accounting Research Group, Netherlands.

Mcnair, C. J., \& Vangermeersch, R. (1996). The fall of management accounting: The NIRA and the homogenization of cost practices in the United States. Research Monograph- Cga Canada Research Foundation, (23), 39-58.

Mia, M. A. H., \& Ahmad, F. (2005). Strategic management accounting practices in the 21st Century. The Cost and Management, 33(4), 44-49.

Ministry of Industry and Trade. (2007). Jordan. Available: http://mit.gov.jo [1/4, 2007].

Moores, K., \& Yuen, S. (2001). Management accounting systems and organizational configuration: a life-cycle


http://dx.doi.org/10.1016/S0361-3682(00)00040-4

Naranjo-gil, D., \& Hartmann, F. (2007). Management accounting systems, top management team heterogeneity and strategic change. Accounting Organizations and Society, 32(7-8), 735-756. http://dx.doi.org/10.1016/j.aos.2006.08.003

Näsi, S., \& Rohde, C. (2006). Development of cost and management accounting ideas in the Nordic countries. In: Chapman, S. et al. (Eds.), Handbooks of Management Accounting Research (pp. 1091-1118). London: Elsevier.

Okano, H., \& Suzuki, T. (2006). A history of Japanese management accounting. In Chapman, S. et al. (Eds.), Handbooks of Management Accounting Research (pp. 1119-1137). London: Elsevier. http://dx.doi.org/10.1016/S1751-3243(06)02024-4

Paige, K. L. (1990). Perceived deficiencies in the use of management accounting information practices by nonprofit managers. Proceedings of the Annual Meeting Decision Sciences Institute, (V1), pp. 137-139.

Perera, S. (2004). The impact of contextual changes on management accounting practices: evidence from a government trading enterprise in Australia. International Journal of Accounting Auditing and Performance Evaluation, 1(4), 465-492. http://dx.doi.org/10.1504/IJAAPE.2004.006357

Silvola, H. (2005). Management accounting practices. (A contingency perspective based on the organizational life cycle, venture capital investors and the education of CEO). Research Paper edn. University of Oulu, OuluFinland.

Smith, J. A., Morris, J., \& Ezzamel, M. (2005). Organisational change, outsourcing and the impact on management accounting. British Accounting Review, 37(4), 415-441. http://dx.doi.org/10.1016/j.bar.2005.07.004

Spraakman, G. P. (1999). Management accounting at the historic Hudson's Bay Company: A comparison to 20th century practices. Accounting Historians Journal, 26(2), 35-64.

Spraakman, G., \& Margret, J. (2005). The transfer of management accounting practices From London counting houses to the British North American fur trade. Business \& Financial History, 15(2), 101-119. http://dx.doi.org/10.1080/09585200500121108

Strauss, P. S. (1992). Managing change. (Management of an accounting practice.). New York: New York State Society of CPAs. http://www.nysscpa.org/cpajournal/old/12106231.htm edn.

Sulaiman, M. B., Ahmad, N. N., \& Alwi, N. (2004). Management accounting practices in selected Asian countries: A review of the literature. Managerial Auditing Journal, 19(4), 493-508. http://dx.doi.org/10.1108/02686900410530501

Sulaiman, S., \& Mitchell, F. (2005). Utilising a typology of management accounting change: An empirical analysis. Management Accounting Research, 16(4), 422-437. http://dx.doi.org/10.1016/j.mar.2005.03.004

Szychta, A. (2002). The scope of application of management accounting methods in Polish enterprises. Management Accounting Research, 13(Part 4), 401-418. http://dx.doi.org/10.1006/mare.2002.0198

Triest, S. V., \& Elshahat, M. F. (2007). The use of costing information in Egypt: a research note. Journal of Accounting and Organizational Change, 3(3), 329-343. http://dx.doi.org/10.1108/18325910710820328

Vieira, R., \& Hoskin, K. (2005). Management accounting practices and discourses change: The role and use of management accounting systems. Working Paper edn. Universidade Nova de Lisboa. Portugal. 
Waweru, N. M., Hoque, Z., \& Uliana, E. (2005). Management accounting change in South Africa: Case studies from retail services. Accounting, Auditing \& Accountability Journal, 17(5), 675-704. http://dx.doi.org/10.1108/09513570410567773

Wijewardena, H., \& De Zoysa, A. (1998). A comparative analysis of management accounting practices in Australia and Japan: an empirical investigation. Asian-Pacific Conference on International Accounting Issues, (10th), pp. 72-76. http://dx.doi.org/10.1016/S0020-7063(99)80003-X

Wu, J., \& Drury, C. (2007). An exploratory study on the environmental factors influencing the adoption of MAPs in Chinese SOEs and JVs. Journal of Technology Management in China, 2(1), 54-70. http://dx.doi.org/10.1108/17468770710723622 